\title{
The current scenario of Covid-19 in Chittagong Metropolitan area, Bangladesh: A survey Study
}

\author{
Shahidul Islam ${ }^{1 *}$, Farhana Hoque ${ }^{1}$ and Moushume Chowdhury ${ }^{1}$ \\ ${ }^{1}$ Department of Pharmacy, University of Science and Technology Chittagong (USTC), Chattogram, Bangladesh.
}

*Corresponding Author: Shahidul Islam, Assistant Professor, Department of Pharmacy, University of Science \& Technology Chittagong, Bamgladesh.

Received Date: August 19, 2021; Accepted Date: August 29, 2021; Published Date: September 25, 2021

Citation: Shahidul Islam, Farhana Hoque and Moushume Chowdhury (2021) The current scenario of Covid-19 in Chittagong Metropolitan area, Bangladesh: A survey Study. J Pharmaceutics and Pharmacology Research. 4(3), DOI: 10.31579/2693-7247/043

Copyright: @ 2021 Shahidul Islam, This is an open access article distributed under the Creative Commons Attribution License, which permits unrestricted use, distribution, and reproduction in any medium, provided the original work is properly cited.

\begin{abstract}
Coronavirus disease 2019 (COVID-19), caused by severe acute respiratory syndrome coronavirus 2 (SARS-CoV-2), has induced a sense of panic around the world as the disease is highly contagious and has been spreading in full swing. This study was aimed to investigate SARS-CoV-2 associated epidemiology and clinical outcomes in Bangladesh in order to understand the future course of COVID-19 pandemic and develop prevention approaches. A cross-sectional retrospective interview based study was conducted on RT-PCR confirmed COVID-19 patients admitted in Chattagram Maa O Shishu General Hospital Chittagong, Bangladesh and who recovered four weeks prior to the interview date. Of the total 500 patients, $7 \%$ patient are asymptomatic where as for the symptoms associated with COVID-19 fever (85\%) and cough (70\%) were the most prominent among cases. Our study has revealed that among the age groups, the $40-70$ showed the highest infection rate $(74.7 \%)$ and in terms of gender, the prevalence of Covid-19 infection in males $(65 \%)$ was 2 times more than that in females (35\%). Diabetes was found about (40\%) and Hypertension was found (42\%), so diabetic and hypertesive patient are more affected. The most used drug is Enoxaparin sodium, Methylprednisolone Na Succinate, Montelucast, fexofenadinb, Doxycyclline, Doxofylline, zinc, vitamin-C, D and about $60 \%$ patient need oxygen supply. The most complication after recovery is weak -fatigue, cough \& breathing problem.
\end{abstract}

Key words: Covid-19, survey, epidemiology, post Covid-19 complications

\section{Introduction}

COVID-19 is a very new disease and there is also still finding out concerning it. It is currently considered that virus too much spreads by joining itself to the droplets in air then enter body through our mucus membranes like in eyes, nose and also mouth [1]. It is very important that effective measures must be taken to prevent the people showing such symptoms passing on virus to the others. Very beginning on the 31 December 2019, Chinese authorities accounted to World Health Organization a rising novel corona virus in the patients from Wuhan, Hubei province [2]. Presently this virus is distinguished as severe the acute respiratory syndrome corona virus 2 (SARS-CoV-2), and the disease name is corona virus disease 2019 (COVID-19). This virus also has a high degree of the lethality than other the endemic viruses and also it is more lethal to the humans compared to earlier emerging epidemics of SARS-CoV-1 in 2003 and Middle East respiratory syndrome coronavirus (MERS-CoV) in 2012. Both SARS-CoV-1 and MERS-CoV have common ancestry with viruses found in bats. Both have transitional hosts for the transmission like palm civets for the SARS-CoV-1 and also dromedary camels for MERS-CoV. However, there is not yet strong evidence for an intermediate host [3]. The current pandemic is caused by SARS-CoV-2. It shares with the earlier two coronaviruses the features of the Coronaviridae family [4]. The Coronavirus have huge ( $30 \mathrm{~kb})$ single-stranded and positive-sense RNA genomes as well as genome is approximately $80 \%$ identical with the other coronaviruses at the nucleotide level. A new virus closely recounted (sharing $90 \%$ of nucleotide structure) to the SARS-CoV-2 is RaTG13-2013 which was identified in bats [5]. The whole genome of the SARS-CoV-2 inaccessible from Wuhan $\mathrm{Hu}-1$ is also available online [6]. The genetic epidemiology of the hCoV-19 and also submitted statistics since December 2019 are available from the GISAID database [7]. Four major structural proteincoding genes have been identified in the corona viruses: spike protein $(\mathrm{S})$, envelope protein $(\mathrm{E})$, membrane protein $(\mathrm{M})$ and nucleocapsid protein $(\mathrm{N})$ [8]. The spike protein of SARS-CoV-2 develops angiotensin-converting the enzyme 2 (ACE2) as its own cell surface receptor and also utilization influences the tropism of the virus.COVID-19 infects people of all ages. However, there are two also main groups at the higher risk of the developing cruel disease such as older people and also people with the underlying comorbidities like diabetes mellitus, cardiorespiratory disorders, hypertension, chronic liver diseases and also renal failure. Respiratory system is primary system affected in the SARS-CoV-2, and also multiple infiltrates of the both lungs can be present. Real-time PCR (RT-qPCR) intensification of the SARS-CoV-2 virus nucleic acid of the nasopharyngeal swabs or else sputum is also needed to confirm diagnosis. However, the test may be negative in the early days of presentation [9]. 
Clinical picture including shortness of the breath, decreased oxygen saturation, increased respiratory rate and also raised C-reactive protein, is very nonspecific. Supplementary tests like $\operatorname{IgG}$ and also IgM antibodies against SARS-CoV-2, $\mathrm{CD}^{+}$and $\mathrm{CD}^{+}$, ought to be ordered. Both $\mathrm{CD}^{+}$and $\mathrm{CD}^{+}$are also substantially lowered in the SARS-CoV-2. Pathology of lungs shows the microscopic bilateral diffuse alveolar harms, cellular fibromyxoid infiltrates and also interstitial mononuclear inflammatory infiltrates with the lymphocyte domination [10]. History and physical examination are extremely important for the diagnosis of COVID-19 infection. General related symptoms such as fever (in $44 \%$ of the patients on appearance and also up to the $88 \%$ of admitted tolerant); shortness of breath, dry cough which can be severe and also progressive, predominantly when patient develops myalgia, pneumonia and also tiredness, nausea, sore throat, vomiting and diarrhea [11]. Patients can have neurologically transmitted symptoms such as acute cerebrovascular disease, dizziness, headaches, seizure, and encephalopathy, decreased level of consciousness and agitation and also confusion. In recent times anosmia, hyposmia and also dysgeusia have been accounted Physical signs contain raised the body temperature, decreased oxygen saturation, increased respiratory rate, auscultation of lungs can be normal or illustrate crackles and also signs of the heart failure, acute coronary syndrome, cardiac arrhythmias, myocarditis, shock and also death could occur [12].

\section{Methodology:}

- The study was conducted among COVID-19 positive patients confirmed by RT-PCR using both Nasopharyngeal and Oropharyngeal swabs as clinical specimens.

- We also categorized all positive patients into two categories(symptomatic and asymptomatic) according to the presence of any one of the established symptoms referred by WHO and CDC

- $\quad$ The RT-PCR test was performed using Novel Coronavirus (2019nCoV) Nucleic Acid Diagnostic Kit (PCR-Fluorescence Probing) by Sansure Biotech Inc. in Institute of Epidemiology Disease Control and Research (IEDCR) approved labsin Bangladesh.

- This study was based on a sample of 250 in-patients who were diagnosed with COVID-19 seeking care in Chattagram Maa O Shishu General Hospital Chittagong, Bangladesh between 9 June 2020- 10 July 2020 and 20 January 2021- 20 February 2020. A self-reported questionnaire written in Bangla \& English was employed to collect data during the survey.

\section{Results and Discussion}

\section{Gender Distribution:}

\begin{tabular}{|l|l|}
\hline $\begin{array}{l}\text { Total Number of } \\
\text { Patient }\end{array}$ & $\mathbf{5 0 0}$ \\
\hline Male & $\mathbf{3 2 6}$ \\
\hline Female & $\mathbf{1 7 4}$ \\
\hline Diabetic Patient & $\mathbf{2 0 0}$ \\
\hline $\begin{array}{l}\text { Hypertension } \\
\text { patient }\end{array}$ & $\mathbf{2 1 0}$ \\
\hline Asthma & $\mathbf{2 6}$ \\
\hline
\end{tabular}

Table 1: the total number of patient is 500 (100\%) where the number of male is $326(65 \%)$ \& female $174(35 \%)$, so male are highest affected than female and the number of diabetic patient 200(40\%), Hypertention (42\%), Asthmatic 26(5\%), most of the patient are having diabetes \& hypertension.

\section{Age Range:}

\begin{tabular}{|l|l|}
\hline Age Age Range & Number of Patient \\
\hline $\mathbf{3 0 - 4 0}$ & $\mathbf{7 0}$ \\
\hline $40-50$ & 130 \\
\hline $\mathbf{5 0 - 6 0}$ & 100 \\
\hline $60-70$ & 140 \\
\hline $\mathbf{7 0 - 8 0}$ & 60 \\
\hline
\end{tabular}

Table 2: the highest number of patient age range is (60-70), in this age the number of patient is 140 (28\%), the lowest number of patient age range is (70-80), in this age the number of patient is $60(12 \%)$ and from age (40-70) the patient are more affected.

\section{Sign and Symptom}

\begin{tabular}{|l|l|}
\hline Symptom & Number of patient \\
\hline Fever & $\mathbf{4 3 0}$ \\
\hline Dry Cough & $\mathbf{3 5 0}$ \\
\hline Respiratory distress & $\mathbf{1 0 0}$ \\
\hline Tiredness & $\mathbf{7 6}$ \\
\hline Sore throat & $\mathbf{7 6}$ \\
\hline Chest pain & $\mathbf{4 0}$ \\
\hline Asymptomatic & $\mathbf{3 4}$ \\
\hline
\end{tabular}

Table $3 ; 34$ patient $(7 \%)$ are asymptomatic, they do not show any covid19 symptom which is declared by WHO. Most common symptom is fever (85\%) \& dry cough $(70 \%)$

\section{Used Drugs:}

Here (Table 4) In case of injectable drug most patient $360(75 \%)$ are prescribed Enoxaparin sodium, 300(60\%) are prescribed Methylprednisolone Na Succinate, 224(45\%) are prescrived Remdesivir.

\section{Oral Care}

\begin{tabular}{|l|l|}
\hline Drug & Number of patient \\
\hline Oxygen & 300 \\
\hline Cholecalciferol vit-D3 & 150 \\
\hline Zinc sulphate & 300 \\
\hline Vitamin-c & 300 \\
\hline
\end{tabular}

Table 5: about (60\%) patient need oxygen support, to boost immune system about (60\%) patient are prescribed vitamin-c \& zinc sulphate and $(30 \%)$ patient are prescribed Cholecalciferol $+v i t-D 3$

\section{Recovery Time:}

\begin{tabular}{|l|l|}
\hline Recovery time (Days) & No Of Patient \\
\hline 8 & 160 \\
\hline 10 & 170 \\
\hline 14 & 150 \\
\hline 20 & 36 \\
\hline 30 & 14 \\
\hline
\end{tabular}

Table 6: most of the patient (90\%) recovered in 8-14 days, 32\% (8 days) and $30 \%$ (10 days)

7. Complications After recovery:

\begin{tabular}{|l|l|}
\hline Problem & No Of Patient \\
\hline Weak \& Fatigue & 300 \\
\hline Cough & 76 \\
\hline Shortness Of Breath & 76 \\
\hline Mental Distress & 26 \\
\hline
\end{tabular}

Table 7: After recovery $60 \%$ patient feel weak \& fatigue, $15 \%$ feel cough \& shortness of breath and (5\%) are feeling mental distress after 


\section{recovery from covid-19.}

\section{Conclusion}

This study has exposed that among age groups, from 40-70 illustrated the highest infection rate $(74.7 \%)$ and also in terms of sexual characteristics, the occurrence of Covid-19 infection in males $(65 \%)$ was 2 times more than that in females (35\%). Diabetes was originated about (40\%) \& Hypertension was got (42\%), so diabetic and also hypertesive patients are much more affected. Moreover $7 \%$ patients are also asymptomatic whereas for symptoms associated with the COVID-19 fever (85\%) and also cough $(70 \%)$ were the most significant among cases. The most widely used drugs are Remdesivir, Enoxaparin sodium, Montelucast, Doxycyclline, fexofenadin, vitamin-C, D, Doxofylline, zinc and approximately $60 \%$ patient require oxygen supply. The most difficulty after recovery of patient is weak -fatigue, cough and also breathing problem. This is presumed that the outcomes of this important study will work as the baseline for near future studies in same perspective.

\section{Reference}

1. Yasmin R, Parveen R, Al Azad N, Deb SR, Paul N, Haque MM, et al.(2020) Corona Virus Infection among Healthcare Workers in a COVID Dedicated Tertiary Care Hospital in Dhaka, Bangladesh. Journal of Bangladesh College of Physicians and Surgeons 43- 9.

2. Hoffmann M, Kleine-Weber H, Schroeder S, Krüger N, Herrler T, Erichsen S,et al. (2020) SARS-CoV-2 cell entry depends on ACE2 and TMPRSS2 and is blocked by a clinically proven protease inhibitor. Cell.

3. yeon Lee J, Hong SW, Hyun M, Park JS, Lee JH, Suh YS, et al.(2020) Epidemiological andclinical characteristics of coronavirus disease 2019 in Daegu, South Korea. International Journal of Infectious Diseases.

4. Guo T, Fan Y, Chen M, Wu X, Zhang L, He T, et al.(2020). Cardiovascular implications of fataloutcomes of patients with coronavirus disease 2019 (COVID-19),JAMA cardiology.
5. Wan S, Xiang Y, Fang W, Zheng Y, Li B, Hu Y, et al 2020). Clinical features and treatment ofCOVID_19 patients in northeast Chongqing. Journal of medical virology.

6. Hellewell, J., Abbott, S., Gimma, A., Bosse, N. I., Jarvis, C. I, et al (2020). Feasibility of controlling COVID-19 outbreaks by isolation of cases and contacts, the Lancet Global Health. doi: 10.1016/s2214-109x(20)30074-7.

7. West, C. P., Montori, V. M., \&Sampathkumar, P. (2020). COVID19 Testing: The Threat of False-Negative Results. Mayo Clinic Proceedings, doi: 10.1016/j.mayocp.2020.04.004.

8. Bhuiyan, A. K. M. I., Sakib, N., Pakpour, A. H., Griffiths, M. D., \&Mamun, M. A. (2020). COVID-19-Related Suicides in Bangladesh Due to Lockdown and Economic Factors: Case Study Evidence from Media Reports. International Journal of Mental Health and Addiction. doi: 10.1007/s11469-020-00307-y.

9. Anwar, S., Nasrullah, M., \& Hosen, M. J. (2020). COVID-19 and Bangladesh: Challenges and How to Address Them, Frontiers in Public Health, 8. doi:10.3389/fpubh.2020.00154.

10. Alam, M., Alam, M. Z., Nazir, K. N., \& Bhuiyan, M. A. (2020). The emergence of novel coronavirus disease (COVID-19) in Bangladesh: Present status, challenges, and future management. Journal of Advanced Veterinary and Animal Research, 7(2), 198208.

11. Hossain, M., Ferdous, S. and Siddiqee, M., (2020). Mass Panic during Covid-19 Outbreak- A Perspective from Bangladesh as a High-Risk Country, Journal of Biomedical Analytics, 3(2), 1-3. doi: 10.30577/jba.v3i2.40.

12. Mannan, DrKazi Abdul and Mannan,(2020) Kazi Abdul, Knowledge and Perception towards Novel Coronavirus (COVID 19) in Bangladesh (2020), International Research Journal of Business and Social Science, vol.6, no.2, doi: $10.2139 /$ ssrn. 3576523 .

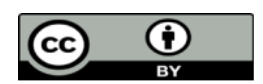

This work is licensed under Creative Commons Attribution 4.0 License
To Submit Your Article Click Here: Submit Manuscript

DOI: $10.31579 / 2693-7247 / 043$
Ready to submit your research? Choose Auctores and benefit from:

> fast, convenient online submission

$>$ rigorous peer review by experienced research in your field

$>$ rapid publication on acceptance

$>$ authors retain copyrights

$>$ unique DOI for all articles

$>$ immediate, unrestricted online access

At Auctores, research is always in progress.

Learn more auctoresonline.org/journals/pharmaceutics-andpharmacology-research 